tricity in which the light quantum passes completely to matter, that is, the photon is annihilated. As one would expect from the author, wave mechanics is treated with great clearness and thero is no attempt to represent the theory as having resolved all diffi. culties; on the contrary, at each partial success its incomplete nature is commented on and the requirements of a more complete solution are specified.

\section{Egg Storage}

A Descrirriox is given in the Electrical Review of September 15 of the Chelmsford Egg Supply Co. (193.1). This company utilizes a process for the preservation of eggs which, it is claimed, keeps them fresh indefinitely. It is said that, if eggs are frozen below $28^{\circ} \mathrm{F}$. they crack, so that storage by freezing is imprasticable. Storage in gas is better, but it takes time for the gas to percolnte through the shell. The company has, however, overcome this difficulty. Fiery egg has a small air space at the top. 'This increases as the egg ages. By means of a pump tho air is extracted and replaced by carbon dioxido and nitrogen under a pressure of $250 \mathrm{~mm}$., this pressure being maint ained all the time the eggs are in storage. The eggs aro stored in large cylinders each holding 234,000 eggs and are kept at a temperaturo of $30^{\circ} \mathrm{F}$. Ench refrigerating unit is driven by a 6 h.p. motor, and in addition, two extra motors are cmployed, 5 h.p. and $2 \cdot 75$ h.p. respectively, for circulating tho water and ammonia. The gas.tight cylinders in which the eggs aro stored look like large boilers. An additional chamber held at a much lower temperature is used for freezing liquid eggs, that is, those which have been accidently cracked, and aro sold to local bakeries. Tho factory is also a national mark packing station capable of dealing with a million and a half eggs a week. Tho electricity taken per annum from the public supply is nearly 60,000 units. As this load is very nearly constant, and is heaviest during tho summer montlıs, the load factor is excellent and an attractive tariff is available. The seasonal differenco in the price of eggs practically makes up for the cost of storage.

\section{Extensions of Carrier Telephone Systems}

Is the quarterly edition (No. 17) of Nippon Electrical Engincering, published in English by the Institute of Electrical Communication Engineers of Japan, there is an important paper on carrier telephone systems which make use of lighting and power distribution lines. It is written by $\mathbf{N}$. Shinohara, $\mathbf{Y}$. Hirano and M. Yoshioka, and contains many useful experimental and theoretical results. They point out that the economies effected by using existing power and lighting circuits as part of the carrier system make it possible to extend communication to out-of-the-wny districts, as, for example, farming listricts, fishing villages, lighthouses, etc. This will unake possible the rapid cultural development of these places. They consider first of all the use of high-tension distribution lines as part of the carrier frequency transmission circuit. In the past this has been done by two systems; the first is called the metallic circuit system and the second the ground return circuit system. Although the first system oxcels the latter so far as low attenuation and noise are concerned, the second is the system which is moro commonly employed owing to its greater economy and trustworthiness. The authors state that in utilizing the high-tension distribution line it is best to employ the ground return circuit system. Tho most commonly employed types of high-tension systems are the single-phase two-wiro type and the threo-phase three-wiro type. The height of the wires above the ground is not uniform, but, whero the lins is oven, the averago height is about seven metres. By considering a singlo copper wiro $5 \mathrm{~mm}$. in diameter at a height of 7 metres above the ground and at a temperature of $20^{\circ} \mathrm{C}$. and $\Omega$ frequency of $50 \mathrm{kc}$., they compute that the speed of the carrier waves is nearly equal to the speed of light and that the attenuation constant is very small. Thoy concludo by describing a method of designing a circuit by a new telephone system which they state will bo the most suitable for a rural district. They show how much moro economical the new system would be than the one at present in use.

\section{Oceanographical Results from Central America}

In July and August 1938, the President of the United States, the Honorable Franklin D. IRooserelt, undertook un inspection eruise and fishing expedition from San Diego, California, to I'ensazola, Florida, by wny of the Panama Canal, aboard the U.S.S. Houston. Between July 16 and August 9 some 5,888 miles were covered and fourteen different collecting stops wero made, distributed among the possessions of five different nations: Mexico (Lower California and Socorro Island), France (Clipperton Island), Ecuador (tho Galapagos Islands), Costa IRica (Cocos Island), and Colombia (Old Providence Island in the Caribbean). Dr. Waldo L. Schmitt of the United States National Museun accompanied tho expedition as a naturalist. The results are published in a series of papers of which four are before us: "Decapod and Other Crustacea" (with Introduction and Data) (Smithsonian Miscellaneous Collections, 98, No. 6, Pub. 353I) by Waldo I. Schmitt; "Molluscs" (Pub. 3535 ) by Paul Bartsch and Harald Alfred Rehder; "A New Holothurian of the Genus 'Thyone" (Pub. 3537) by Elisabeth Deichmann; and "I'wo New Gobioid Fishes" by Isaac Ginsburg (Pub. 3539), May-June 1939. A number of new species of Mollusca are described, and lists of species given from tho various collecting grounds.

\section{Grass Drying}

A nEPOnT on fodder conservation with special reference to grass drying by F. J. Roberts has been published by the Agricultural Research Council (H.M. Stationery Office. 2s.). This is the third report on the subject, and embodies the results of the most recent experiments carried out with the co-operation of agricultural organizers, colleges and experi. mental farms in Great Britain. A detailed account 
of grass-drying machinery and equipment is given, and comparison mado with tho various processes of artificial drying in other countries. Thero seems to bo littlo doubt that the conservation of young grass is sound in principlo, as it is then at its maximum nutritive value, and feeding trials show that it can largely replace concentrates. The question of the profitableness of grass-drying, however, cannot bo answered so simply, as it depends.both on the quality of the product and also on other matters such as the market value of the concentrates which it is to substitute, and whether the grass would have been utilized in somo other manner or wasted through occurring at a time of surplus growth. Tho indirect advantages of the process, such as improvement of tho sward, control of thistle, etc., must not bo overlooked, nor the fuct that the lower grades of dried grass are of higher value than tho best hay. Profitmaking, howover, in this as in many farming enterprises, depends to a very largo extent on tho skill of the individual.

\section{Agricultural Libraries}

THe Internationnl Institute of Agriculture in Romo has just published a useful book of reference entitled "International Directory of Agricultural Librarics" (25 lira). Tho information consists of a list of all general agricultural libraries of moro than two thousand volumes, libraries specialized in particular subjects, agricultural collections in general libraries, and centres of agricultural documentation. So far as possible, the history and size of the library and tho subjects represented therein, the cataloguing and classification systems employed and regulations for the use of the library aro stated. Relations with other libraries (exchange of publications, etc.), a bibliography of writings on tho library and any publications cdited by it aro also mentioned. 1,200 libraries arranged according to country aro described, and the text is written in both English and French.

\section{Theodor Langhans (1839-1915)}

Tryodor IaAvghans, an eminent German pathologist, who with tho physician Sahli and tho surgeon Kocher formed a triumvirato which mado tho Berno medical school famous, was born at Usingen, N'nssau, on September 28, 1839. Ho received his medical education at Heidelberg; Göttingen, where ho was a pupil of the celcbrated anatornist Henlo; Berlin, whero he studied under Virchow, Trauber and Frerichs; and Würzburg, whero he qualified in 1864 with $a$ thesis on the structure of tendons and served as assistant to von Recklinghausen until 1867. Ho then went to Marburg, whero he collaborated with I,ieberkühn and Wagner in nnatomical research. In 1868 ho described the giant cells in tuberclo to which his name has been given, and it was during his stay in Marburg that he carried out some important investigations on the absorption of extravasations and the formation of pigment. In 1872 ho was appointed professor of morbid anatomy at Giessen, but in the same year succeded Klebs in the corresponding chair at I3erne, where ho did valuable work on the morbid histology of the female breast, the histology of the placenta, the distribution of glycogen in normal and diseased organs, and described tho cellular layer of the chorionic epithelium to which his namo has been given. Ho also collaborated with Kocher in a study of diseases of the tosticle. His later years wero rnainly devoted to researches on the morbid anatomy of goitro and cretinism. Ho retired from his chair two years before death, which took place on October $22,1915$.

\section{Announcements}

WE have been aslied to state that the Geological Society of I ondon is carrying on as usual at Burlington House. An announcement relating to meotings will bo mado in due course.

TuE annual oxhibition of tho Royal I'hotographic Society is being held at tho Society's House, 16 Princo's Gato, South Kensington. The exhibition is open from 10 a.m. until 5 p.m. daily (Sundays excepted) until October 7.

Mr. JoHs RYMr.L, tho arctic and antaretic explorer, has been swarded the David I,ivingstono Centenary Gold Medal of tho American Geographical Society in recognition of his leadership of the Graham Isand Expedition. Mr. Rymill, who is an Australian, wns a member of tho British Arctic Air Routo Fxpedition to Greenland in 1930-31, and took over the leadership when Mr. H. G. Watkins was lost. Ho led tho Graham Land Expedition to the Antarctic in 1934 .

Tife Council of the Institution of Nnval Architects has awarded tho Martell scholarship in naval architecture (1939) to NIr. Norman IV. H Ioney, of H.MI. Dockyard, Sheerness; the scholarship is of the valuo of $£ 130$ per annum, and will bo held at tho Royal Naval College, Greenwich. The Farl of Durham Prizo has been awarded to Mr. Peter L. Bish, of 11..I. Dockyard, Devonport.

WE have received from the British Drug Houses, Istd. (Graham Street, London, WV.l.) tho new cataloguo of B.D.H. laboratory chemicals and testing outfits, which comprises nearly six thousand separato items and is provided with $\&$ general index. Section I has been enlarged by moro than five hundred now items, mostly organic chemicals, and Section 2 con. tains an increased number of reagents and solutions for analytical and clinical purposes, and there is a now section of culture media. The products listed are normally held in stock for immediate delivery.

Dr. Albzikt B. Sabin of the Rockefeller Institute of Medical Rescarch has received the Theobald Smith award of 1,000 dollars from the American Association for the Advancernent of Science in recog. nition of his rapid method of typing in pneumonia and for a quick bedside test of a patient's probable resistance to the disease. 